\title{
2. TECTONICS AND SEDIMENTATION IN THE LAU BASIN (SOUTHWEST PACIFIC) ${ }^{1}$
}

\author{
L.M. Parson, ${ }^{2}$ R.G. Rothwell, ${ }^{2}$ and C.J. MacLeod ${ }^{2}$
}

\begin{abstract}
Examination of seismic reflection profiles from the western half of the Lau backarc basin, together with sedimentological and downhole logging data from Ocean Drilling Program Leg 135 drill sites, has allowed us to assess the sedimentary and structural processes operative during arc rifting, and the nature of the transition from rifting to true backarc spreading.

The attenuated arc terrain of the western Lau Basin is characterized by a horst-and-graben morphology. Several of the graben were drilled during Leg 135 . Within each of these fault-bounded sub-basins, a twofold sedimentary infill was recognized: a lower sequence of volcaniclastic gravity-flow deposits overlain by an upper sequence dominated by hemipelagic clay-nannofossil oozes. The thickness and age of each sequence varies from basin to basin. The volcaniclastic deposits at each site appear to be of local derivation, from relict high-standing arc fragments and/or volcanic constructs, and little sediment transport has occurred between basins. Tilting of the sedimentary fill within some of the graben, documented on seismic records and from the drill holes, attests to rotational normal faulting on some of the basin-bounding faults. Reference to the lithostratigraphy of the drill sites shows that the principal phases of activity on these faults took place at different times at the different sites.

We review the likely regional tectonic and volcanic "events" that might have been responsible for the diachroneity of sedimentation and tectonism at each site, and show that the timing of southward propagation of the Eastern Lau Spreading Center through the attenuated arc crust, and transition from arc rifting to true seafloor spreading, correlates with the peak of extensional tectonism and consequent influx of gravity-flow sediments in each of the sub-basins drilled in the western Lau Basin.
\end{abstract}

\section{INTRODUCTION}

\section{Tectonic Setting}

Drilling results from Ocean Drilling Program (ODP) Leg 135 have revealed new insights into the early geological evolution of the Lau backarc basin. They show that a protracted period of extension, rifting, and local arc magmatism occurred between the remnant paleo-arc of the Lau Ridge and the easterly migrating active arc and paleo-arc complex of the Tonga Platform. True seafloor spreading only became established at approximately $5.5 \mathrm{Ma}$, upon the southward propagation of the Eastern Lau Spreading Center (ELSC) through the attenuated remnant arc crust (Parson and Hawkins, this volume). The western half of the Lau Basin (Fig. 1) is floored by the attenuated arc crust formed during this early phase of rifting. Horsts and graben, with a relief often in excess of $1000 \mathrm{~m}$, form the basin floor over much of this terrain. Drilling shows the volcanic basement here to be a heterogeneous assemblage of both MORB-like and arc-like basalts and basaltic andesites (Parson, Hawkins, Allan, et al., 1992).

The boundary between the rifted arc crust of the western Lau Basin and the backarc oceanic crust generated by the ELSC is marked by a series of north-south elongate basins oriented along a $167^{\circ}$ azimuth (Fig. 2). The ELSC propagator initiated at about $5.5 \mathrm{Ma}$ from the southeastern end of a transform structure which is now the site of the Peggy Ridge. The rift tip passed from north to south through the basin with time, advancing to its present position at the southern limit of the Valu Fa Ridge $\left(23^{\circ} \mathrm{S}\right.$ ) at a rate of $120 \mathrm{~km} / \mathrm{m}$.y. (Parson and Hawkins, this volume). A second spreading axis, the Central Lau Spreading Center (CLSC), also started propagating southward from the Peggy Ridge between 1.2 and $1.5 \mathrm{Ma}$, rifting apart the ELSC oceanic crust (Parson et al., 1990). Its rift tip is now at approximately $19^{\circ} 20^{\prime} \mathrm{S}$.

\footnotetext{
'Hawkins, J., Parson, L., Allan, J., et al., 1994. Proc. ODP, Sci. Results, 135: College Station, TX (Ocean Drilling Program).

${ }^{2}$ Institute of Oceanographic Sciences Deacon Laboratory, Wormley, Godalming, Surrey GU8 5UB, United Kingdom.
}

\section{Sedimentation in the Western Lau Basin}

During Leg 135 five sites were drilled in the western part of the Lau Basin (Sites 834, 835, and 837-839). The sites are all located in discrete sub-basins within the horst-and-graben terrain, and form an approximate transect across the rifted arc basement onto crust thought to have been formed at the ELSC (sampled at Site 836).

The sediment sequences recovered from the backarc sites range from the upper Miocene to the Holocene. At each site, a twofold subdivision of the sedimentary succession can be recognized: a lower sequence of volcaniclastic sediment gravity-flow deposits, interbedded with hemipelagic clayey nannofossil oozes and nannofossil clays, is overlain by an upper sequence of hemipelagic clayey nannofossil oozes, with minor calcareous turbidite beds. However, although the overall character of the sediment column at each drill site is similar, the thickness and age of each sequence varies substantially from site to site.

The volcaniclastic sediment gravity-flow deposits that make up much of the lower sequences are almost exclusively of epiclastic (reworked) origin: primary fallout tephras are very rare. The turbidites are composed predominantly of massive vitric sands and silts, with subordinate gravels (Parson, Hawkins, Allan, et al., 1992).

\section{Aims and Methods}

In this synthesis, we attempt to expand and extend the preliminary interpretations by earlier workers of the sedimentation histories of the drill sites. Integration of revised lithostratigraphic interpretations with seismic reflection profiles and structural data from cores and downhole logs helps constrain the style, magnitude, and timing of extension in each of the basins drilled during Leg 135 . We compare and contrast the sedimentary and structural evolution of each site in an attempt to assess the role of local vs. regional tectonic and/or volcanic controls on sedimentation, and to constrain the styles and mechanisms of deformation across the attenuated arc crust of the western Lau Basin.

More than $8000 \mathrm{~km}$ of seismic reflection profiles from the Lau Basin were examined in this study. These data consist of single-channel seismic lines (many of which predate global positioning system 


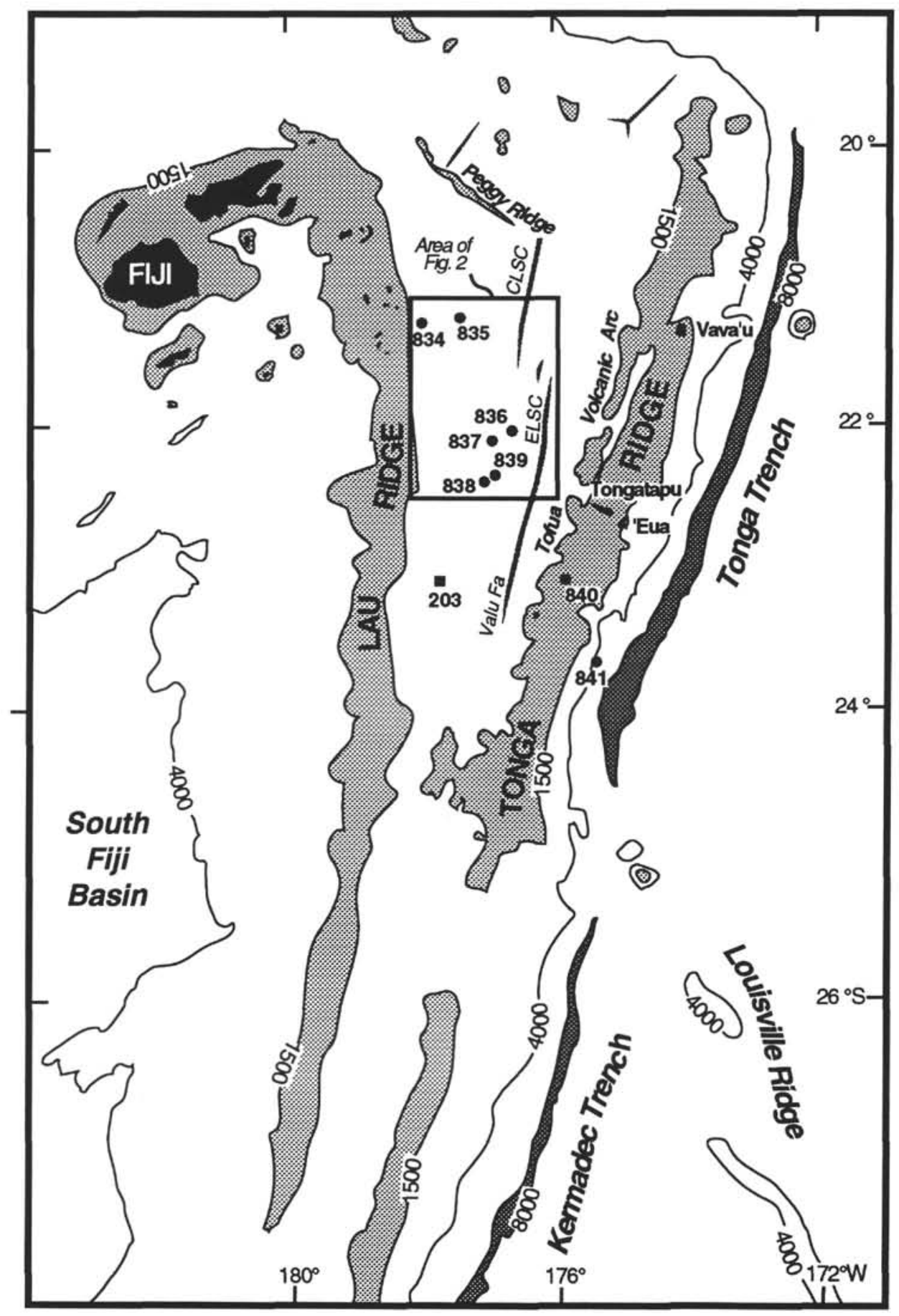

Figure 1. Generalized bathymetric chart of the Lau Basin, illustrating the position of the Leg 135 drill sites and major physiological features. ELSC and CLSC indicate the Eastern Lau and Central Lau spreading centers, respectively. Box outlines the area of Figure 2.

navigation), collected by a number of organizations on the following cruises: the Scripps Institution of Oceanography (SIO) "Southtow" and "Roundabout" cruises; Lamont-Doherty Geological Observatory (LDGO) "Vema," "Conrad," "Eltanin," and "Chain" cruises; Institute of Oceanographic Sciences (IOS) Charles Darwin Cruise 33; and the United States Geological Survey (USGS) S.P. Lee cruise of 1982.

Additional data were collected during Leg 135 as part of the underway geophysics program (Parson, this volume). Multichannel data collected over the Tonga Ridge (Stevenson, 1985; Mann, 1985) have been interpreted by Herzer and Exon (1985) and are therefore not discussed here. Some preliminary processing has been undertaken on the SIO data (and on the JOIDES Resolution tracks; see Bruns et al., this volume), and these enhanced profiles are used in this interpretation.

The morphotectonic setting of the Leg 135 backarc sites (Sites $834-839$ ) is assessed with reference to a new bathymetric compilation map and to a GLORIA sidescan sonar mosaic of the Lau Basin (Parson et al., 1992). In addition to the interpreted seismic reflection profile records, constraints on the structural history of each of the sites come 


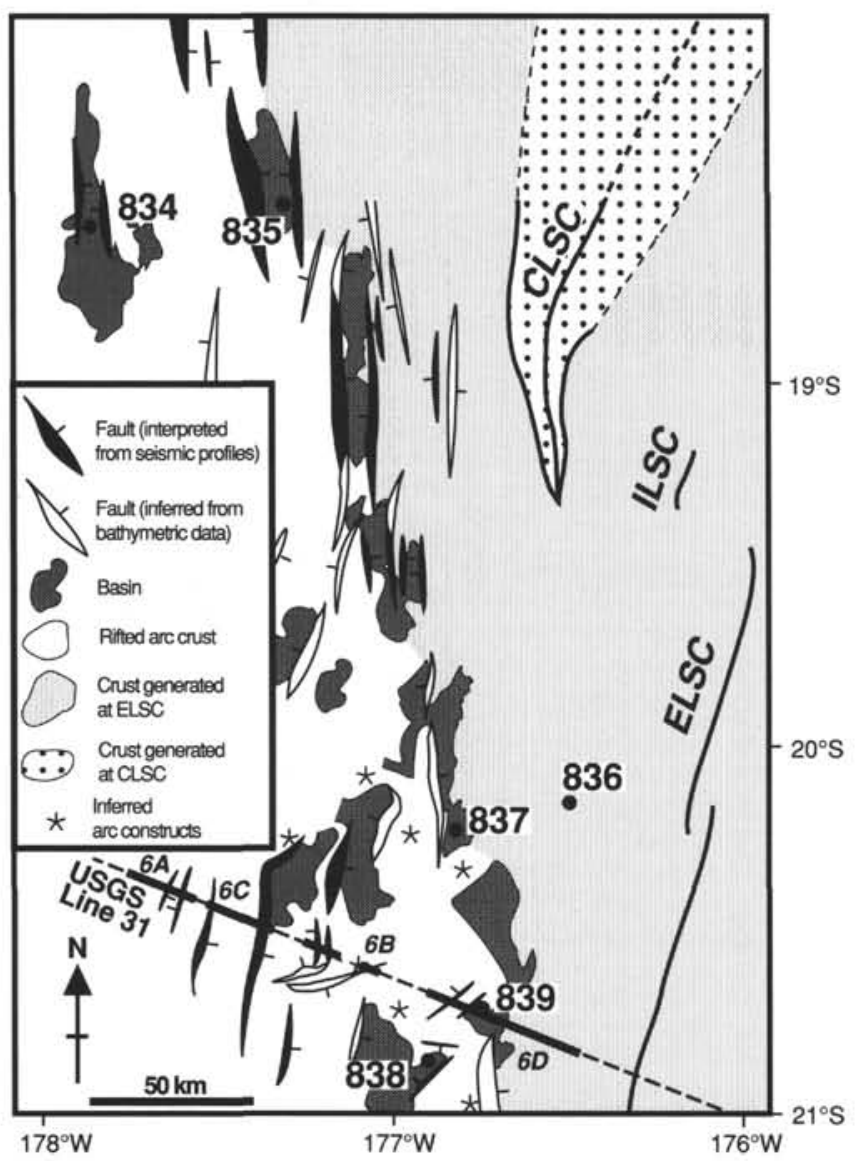

Figure 2. Tectonic synthesis of the central and western Lau Basin, illustrating the principal fault patterns as determined from seismic data (filled fault symbols) and inferred from swath bathymetry data (open fault symbols).

from sedimentary bedding measurements obtained either directly from the core or from downhole logging data. The Formation MicroScanner (FMS) logging tool generates high-resolution electrical images of the borehole wall which, because the tool carries a downhole magnetometer, can be oriented with respect to azimuth. For this study sedimentary bedding orientations were calculated from the FMS resistivity data by "dipmeter" computation (Schlumberger, 1986; also see MacLeod et al., this volume), which derives a mean bedding dip and dip direction measurement per $0.9-\mathrm{m}$ vertical interval of the borehole. True (recombined) bedding dips measured from the core are also discussed here: however, multishot core orientation measurements have not been used: so many problems were encountered with the tool and the data it generated during the cruise (see Parson, Hawkins, Allan, et al., 1992) that we prefer to ignore the results altogether than to attempt to interpret data of dubious reliability.

Detailed lithologic logging of the sediment sequences at each site identified individual turbidites and other types of sediment gravityflow deposits, using compositional and textural criteria for volcaniclastic allochthonous beds and the criteria discussed by Rothwell et al. (this volume) for calcareous mud turbidites. Identification of allochthonous beds within the sediment sequences (Fig. 3) has allowed us to infer episodes of instability, and thus to seek correlation with known or inferred tectonic or volcanic events. Equivalent chronostratigraphic ages for sedimentary horizons were calculated from consideration of average hemipelagic sedimentation rates (about 1.5 $\mathrm{cm} / \mathrm{k} . \mathrm{y}$.; Rothwell, et al., this volume; Reich et al., 1990), in conjunction with shipboard paleomagnetic and biostratigraphic data.

\section{SEDIMENTARY AND STRUCTURAL EVOLUTION OF THE BACKARC BASIN DRILL SITES}

\section{Sub-basin 834}

Site 834 was drilled in a small sub-basin (Figs. 1-2) about $100 \mathrm{~km}$ east of the eastern flank of the Lau Ridge and $150 \mathrm{~km}$ west of the propagating ridge that forms the Central Lau Spreading Center. The sub-basin is about $8 \mathrm{~km}$ wide at the latitude of Site 834 , but it widens to about $14 \mathrm{~km}$ toward the south before narrowing at its southern end (Fig. 4A). The northern limit of the sub-basin is imprecisely known, but the basin must be at least $25 \mathrm{~km}$ long and with a floor area in the order of $500 \mathrm{~km}^{2}$. The sub-basin is surrounded by relatively gentle slopes that rise above the basin floor (at more than $2800 \mathrm{mbsl}$ ) by as much as $1100 \mathrm{~m}$ in the east and $1600 \mathrm{~m}$ in the west. The gradients of the slopes that immediately flank the basin to the east and west are on the order of $3^{\circ}$. Drilling at Site 834 encountered basalt at a depth of $112.5 \mathrm{mbsf}$. The age of the basin-floor lava flows is estimated to be in the range 4-5.6 Ma, based on shipboard biostratigraphic and paleomagnetic data (Parson, Hawkins, Allan, et al., 1992).

The sediment sequence recovered at Site 834 consists of a lower sequence of vitric silts and sands interbedded with hemipelagic clayey nannofossil mixed sediments and nannofossil clays (using the sediment classification of Mazzullo et al., 1987), overlain by a thick sequence of clayey nannofossil ooze that is interpreted as hemipelagic accumulation. Volcaniclastic turbidites are absent from the top part of the sequence (above $42 \mathrm{mbsf}$, dated at $2.4 \mathrm{Ma}$ ) but then increase both in frequency and thickness downhole, especially below $78 \mathrm{mbsf}$ (dated at 3.6 Ma). Although volcaniclastic turbidites are absent from the upper part of the sequence, calcareous turbidite interbeds occur sporadically throughout the upper clayey nannofossil ooze sequence (Fig. 3), with a marked increase both in the frequency of emplacement and bed thickness since $0.2 \mathrm{Ma}$ (Fig. 3). These turbidites contain shallow-water-derived benthic foraminifers and abundant pteropods (Parson, Hawkins, Allan, et al., 1992) and are probably derived from carbonate reefs built up on the eroded Lau Ridge (Rothwell, et al., this volume). Within the lower volcaniclastic-dominated sequence, there is a marked increase in the emplacement of volcaniclastic beds between 3.6 and 4.4 Ma and between 2.4 and 2.9 Ma (Fig. 3), suggesting that these intervals correspond to periods of increased instability. Sediment gravity-flow deposits emplaced during the earlier period show a marked increase in thickness and probably represent proximal deposits that formed mass-wasted detrital aprons adjacent to the basin flanks following basin formation and around volcanic seamounts. After $2.4 \mathrm{Ma}$, emplacement of volcaniclastic turbidites ceased and deposition of hemipelagic sediments with episodes of calcareous turbidite emplacement continued to the present day (Rothwell et al., this volume).

On single-channel seismic records (Parson, this volume), the sub-basin in which Site 834 was drilled is seen to be an approximately symmetrical graben. Fault offset of the basement is $<0.1 \mathrm{~s}$ two-way traveltime [TWT]), estimated to correspond to a throw of approximately $100 \mathrm{~m}$. Note that for this paper we have converted seismic traveltimes to depths in section using a single conversion factor of 1.0 $\mathrm{s}=1 \mathrm{~km}$ of sediments, a figure supported by shipboard physical properties data (e.g., see fig. 51 in Parson, Hawkins, Allan, et al., 1992, p. 547). On the seismic profiles, the basin-fill units appear to be flat-lying. Dipmeter results, however, show a slight but progressive increase in bedding dip toward the west-southwest, from $1^{\circ}$ to $2^{\circ}$ at about $50 \mathrm{mbsf}$ (corresponding to about $3 \mathrm{Ma}$ ) to $3^{\circ}-4^{\circ}$ at $110 \mathrm{mbsf}$ (in sediments dated to $4.4 \mathrm{Ma}$, overlying the shallowest basement), and possibly steeper in the sediment interbed at $\sim 135 \mathrm{mbsf}$ (probably also 4.4 Ma; Parson, Hawkins, Allan, et al., 1992). Dip directions are relatively consistent toward the west-southwest throughout this interval (Fig. 4B). No logging data are available for the uppermost part of the sedimentary sequence, but bedding dips measured from the core are predominantly flat-lying above $50 \mathrm{mbsf}$ and steeper 


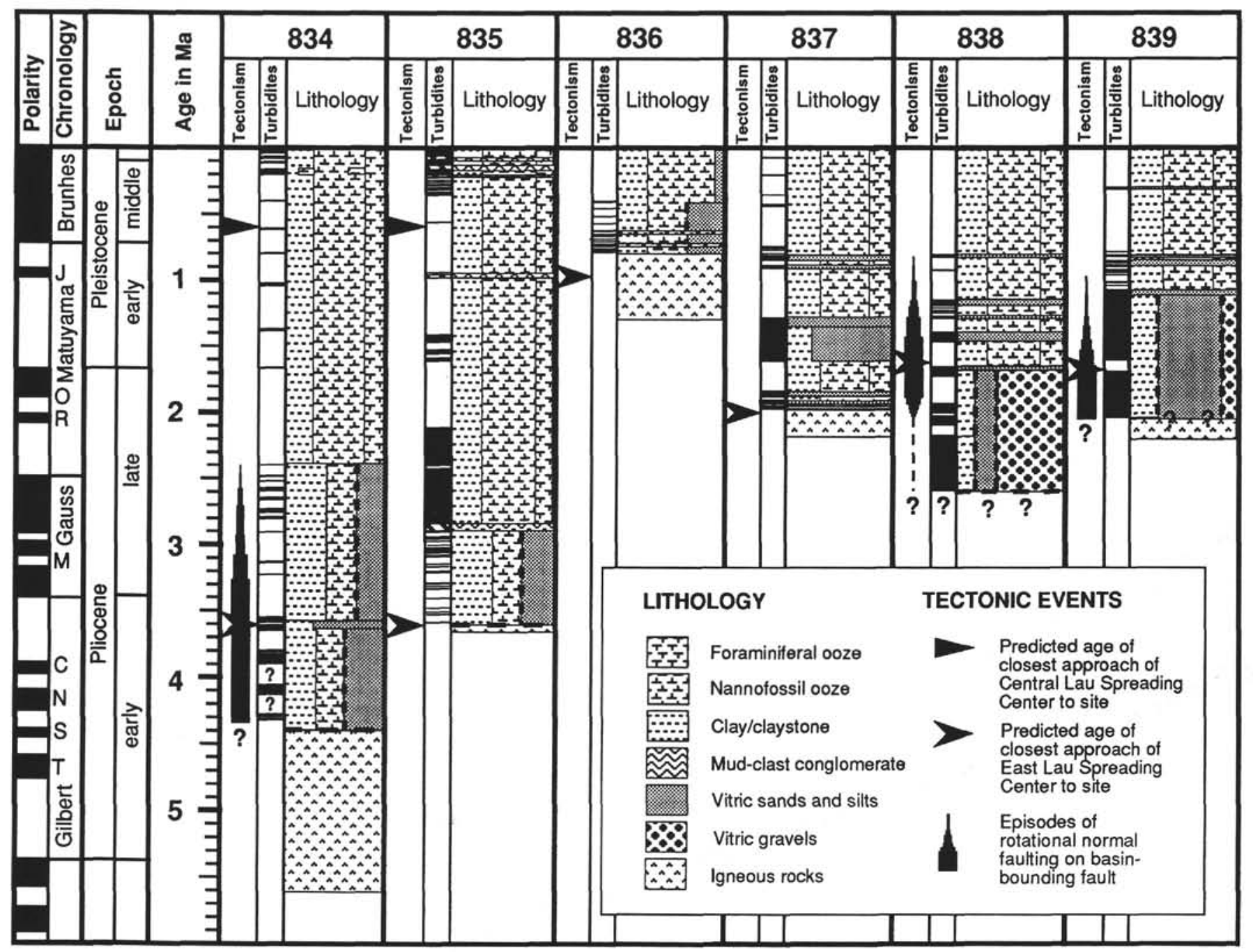

Figure 3. Tectonostratigraphic columns for Sites $834-839$, summarizing the principal sedimentary input to and the timing of rotational faulting in each of the sub-basins. The arrows show the timing of the closest approach of the ELSC and CLSC propagating rifts at the latitude of each site.

below. These observations together suggest that a minor amount of growth faulting took place during the early Pliocene, up until approximately $3 \mathrm{Ma}$, probably about the north-northwest-trending normal fault that bounds Basin 834 to the west (Fig. 2). In contrast, within the sub-basin immediately to the west of, and subparallel to, Basin 834 , the lower volcaniclastic-dominated sediment sequence (approximately $200-400 \mathrm{mbsf}$ ) has an apparent eastward dip of up to $5^{\circ}$ on seismic profiles (Parson, this volume). The dipping reflector sequence in this sub-basin is overlain by planar, subhorizontal basin fill. The regional structure of this pair of basins thus appears to be one dominated by two half-graben, facing inward to a central basement horst located to the west of Site 834 .

Between 3.8 (78 mbsf, corresponding to $3.69 \mathrm{~s}$ TWT) and $4.4 \mathrm{Ma}$ (112 mbsf, corresponding to 3.96 s TWT), sedimentation at Site 834 was dominated by the deposition of thick proximal turbiditic volcanic sands and silts (Fig. 3). These two horizons are separated by a seismic sequence that is almost acoustically transparent and is interpreted as the equivalent of Lithologic Unit II of Parson, Hawkins, Allan, et al. (1992). The thickness of this transparent unit appears to be constant in an east-west direction across the basin. Assuming no significant thickness change from north to south, therefore, we can calculate an approximate volume for Lithologic Unit II of nearly $45 \mathrm{~km}^{3}$.

On seismic sections, the uppermost part of the sequence is characterized by series of offsets or inflections, provisionally interpreted as either minor folds or faults, depending on whether clear dislocation of reflectors is observed. Locally, the fault offsets appear to crop out at the basin floor, and although it is difficult to resolve the amount or sense of displacement on these structures, we recognize that a limited degree of tectonism persists to present day. The locally undulating drape that constitutes the uppermost seismic sequence suggests that the basement structure exerts some control on its deformation, either through differential compaction of the sediments or through syndeformational sedimentation. This sequence corresponds to lithologic Unit I (dominated by hemipelagic clayey nannofossil ooze) and an approximate estimate for its volume, taking into account the uplifted margins to the Unit I/Unit II boundary and the convergence of this horizon with the seafloor, is $37 \mathrm{~km}^{3}$.

\section{Sub-basin 835}

Site 835 was drilled in a well-defined, elongated, parallel-sided, fault-bounded graben (Fig. 2). The sub-basin is up to $20 \mathrm{~km}$ wide at the crests of the flanking walls and $10 \mathrm{~km}$ wide at the basin floor. The basin structure is asymmetric, with a major continuous fault scarp forming the west wall and a more complex and less continuous set of nested fault structures forming the east flank. The water depth of the basin at the drill site is $2913 \mathrm{~m}$ and the scarps surrounding the sub-basin rise above the basin floor by $1400 \mathrm{~m}$ to the west and by 
A.
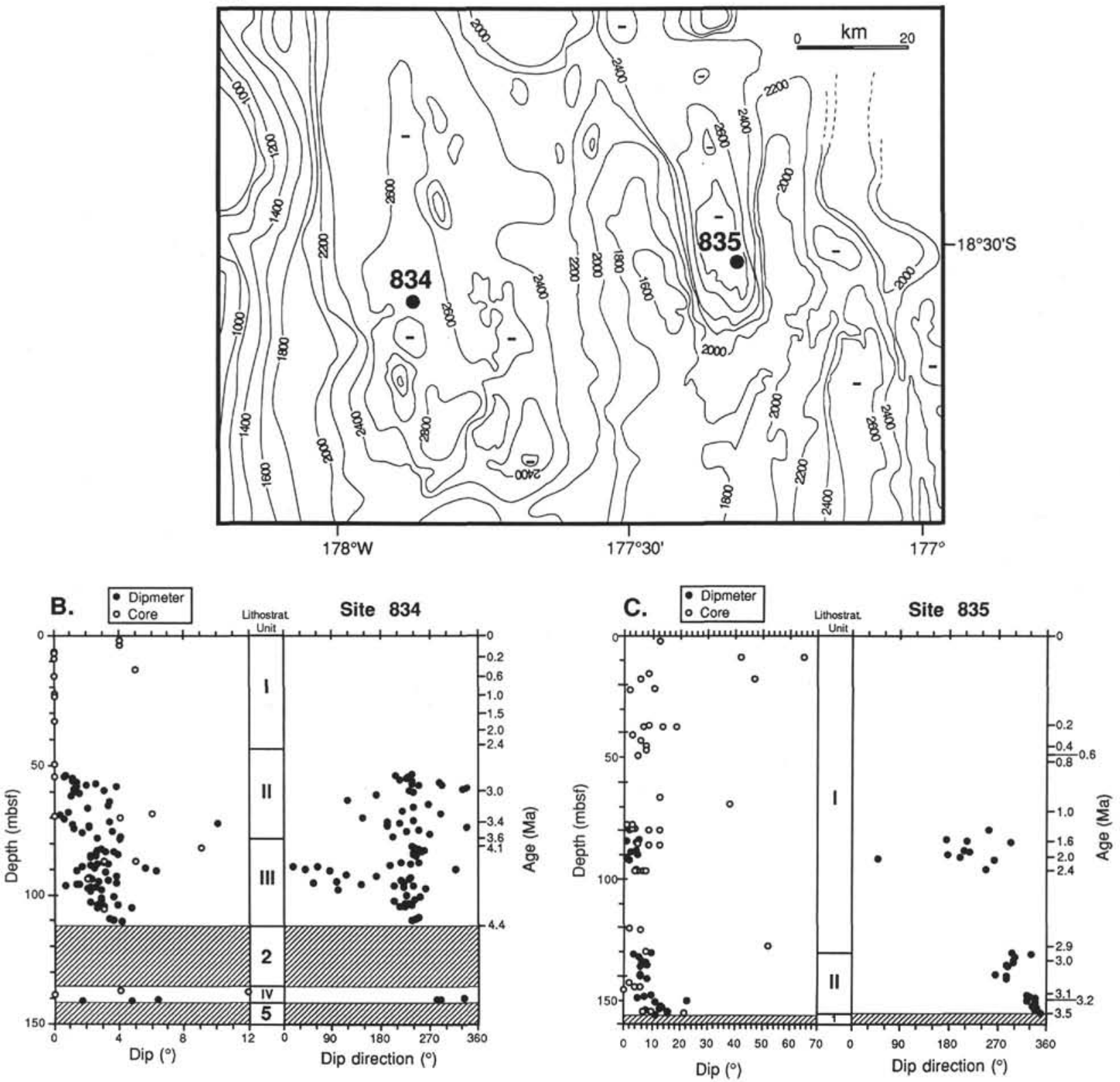

Figure 4. A. Detailed bathymetry in the vicinity of Sites 834 and 835 . B. Dipmeter and core dip measurement summary for Site 834 . C. Dipmeter and core dip measurement summary for Site 835 .

$1100 \mathrm{~m}$ to the east (Fig. 4A). Gradients on the slopes surrounding the basin are very steep, on the order of $10^{\circ}$ to the west, $4^{\circ}-9^{\circ}$ to the south, and $10^{\circ}-30^{\circ}$ to the east. The basin tapers and shoals to the south at $18^{\circ} 35^{\prime} \mathrm{S}$ and is open-ended and deepens to the north. The basin has an approximate area of $160-200 \mathrm{~km}^{2}$.

A number of seismic reflection profiles traverse the sub-basin from east to west (e.g., see fig. 6 in Parson, Hawkins, Allan, et al., 1992, p. 188). Here we describe the structures illustrated in five of those profiles in some detail to demonstrate the rapid along-strike variation in basin tectonic style typical of the western Lau Basin. The northernmost profile (SIO "Roundabout" cruise), at $18^{\circ} 20^{\prime} \mathrm{S}$, shows a single major east-facing normal fault bounding a half-graben that shoals to the east. The fault forms the lower portion of a slope that drops nearly $2 \mathrm{~km}$ over a distance of $12 \mathrm{~km}$ : that is, an average slope of $<10^{\circ}$. At the foot of the fault, the basin is floored by a sequence of almost seismically transparent, flat-lying sediments approximately $0.15 \mathrm{~s}$ TWT in thickness. On the JOIDES Resolution profiles, this unit is underlain by a high-amplitude parallel band of reflectors, which we interpret as acoustic basement, and which can be readily compared to other examples outside of the basin (Parson, this volume). The horst to the west rises to about $750-\mathrm{m}$ water depth and downthrows the basin floor by about $600 \mathrm{~m}$. Nine kilometers to the south, at around $18^{\circ} 25^{\prime} \mathrm{S}$, our profile data indicate the western flank to the basin to be more complex and dominated by a series of at least four small dip-slip faults planes that dip at angles of between $10^{\circ}$ and $45^{\circ}$. Each of the faults has a downthrow of between 180 and $400 \mathrm{~m}$. Rotation of each of the individual fault blocks has resulted in minor back-tilting of the upper surfaces. On the opposite flank at this latitude, a single westerly facing fault downthrows the basin floor by more than $1000 \mathrm{~m}$. On the seismic profiles, the sediment overlying 
both the basin flanks and floor is weakly laminated, but the laminae are locally disrupted. Mounds on the basin floor at the foot of the scarps are interpreted as representing either slump deposits, talus accumulations, or possibly rafted slabs derived by upslope failure.

At $18^{\circ} 30^{\prime} \mathrm{S}$, the latitude of Site 835 , the sub-basin is largely a symmetrical feature, bounded by a pair of inward-facing normal faults each downthrowing more than $1000 \mathrm{~m}$ at fault angles of up to $45^{\circ}$. The nature of the adjacent flanking highs is equivocal. They are each asymmetrical back-rotated basement blocks, inward-facing, with shallowly inclined (between $5^{\circ}$ and $7^{\circ}$ ) outer surfaces. Slump structures, slump folds, and other sediment offsets on the outer block faces suggest some sediment failure on flanks away from the basin. Offsets on faults cutting the seismic sections are seen at the seafloor. These suggestions of recent tectonic activity are confirmed by the sharply defined fault patterns seen on GLORIA long-range sidescan sonar records (Parson et al., 1990, 1992). The $3.5-\mathrm{kHz}$ seismic profiler records have also been interpreted by von Stackelberg et al. (1990) as slumps and other mass-wasting features in this area. Drilling at Site 835 shows that the apparently well-laminated upper part of the sequence in the eastern part of the sub-basin contains a high proportion of redeposited sediments, including muddy debris-flow deposits, coherent rafted blocks, and thick mud turbidites. Reworked material is thought to make up $75 \%$ of the total sediments deposited during the last 2.9 m.y., during which time $133 \mathrm{~m}$ of sediment was deposited at Site 835 (Rothwell et al., this volume). This suggests that persistent periods of instability have been continuing from this time through to the present day (see below).

A large wedge-shaped unit observed within the eastern part of the JOIDES Resolution seismic section crossing Site 835 (see fig. 6 in Parson, Hawkins, Allan, et al., 1992, p. 188) is interpreted as a slump deposit lying within an otherwise flat-lying sequence of lower Pleistocene hemipelagic/turbidite sediments. Although an apparent angular relationship exists between the wedge and the overlying sedimentary section, we recognize no apparent hiatus in deposition, nor angular disconformity in the core (see below). It seems likely, however, from detailed lithostratigraphic studies, that redeposited sediments form a high proportion of the basin fill adjacent to the flanking basin walls (Rothwell et al., this volume).

Seismic reflection profile data recorded at $18^{\circ} 35^{\prime}$ S (SIO "Roundabout" cruise, approximately $10 \mathrm{~km}$ south of Site 835 ) indicates the basin width to be approximately $20 \mathrm{~km}$ between the tops of the flanking horsts, and approximately $10 \mathrm{~km}$ wide at the level of the basin floor. The shapes of the walls and floor of the sub-basin at this latitude are largely configured by a number of inward-facing faults. The total downthrow on the dominant easterly facing flank is approximately $1000 \mathrm{~m}$. The upper $0.2 \mathrm{~s}$ TWT of the seismic section throughout the profile is dominated by a sequence of sub-parallel, highamplitude reflectors. Below $0.25 \mathrm{~s}$ TWT lies a ubiquitous, acoustically opaque unit referred to here as "acoustic basement." Fault blocks are slightly back-rotated, and in at least one example, the resultant narrow half-graben is infilled by a seismically laminated unit, presumably a sequence dominated by locally derived turbidites emplaced during basement rifting.

At latitude $18^{\circ} 42^{\prime} \mathrm{S}$, approximately $22 \mathrm{~km}$ to the south of Site 835 , the SIO "Roundabout" cruise seismic profile shows a very different structure to the sub-basin than that farther north. Whereas a single fault with a downthrow of some $400 \mathrm{~m}$ delineates the western flank, the eastern margin of the basin is poorly defined, with a series of irregular basement highs approximately $5 \mathrm{~km}$ in width separating roughly flat-lying sub-basins of the same dimension. To the west of, and within Sub-basin 835 , a seismically well-layered, coherently bedded sequence dominates the upper $0.2-0.25 \mathrm{~s}$ TWT of the seismic profile; this is interpreted as hemipelagic sediment as it mantles the irregular topography. In contrast, the narrow basin adjacent to the foot of the western flank contains a thicker, flat-lying sequence, which presumably contains a significant proportion of turbidites and other sediment gravity-flow deposits.
Drilling at Site 835 recovered a sedimentary sequence of clayey nannofossil oozes and mixed sediments, foraminiferal sands, mudclast conglomerates, and proximal turbiditic volcanic silts that consist largely of felsic volcanic glass (Parson, Hawkins, Allan, et al., 1992). These volcanic silts are very rare in the upper $130 \mathrm{~m}$ of the sediment column, which is instead dominated by autochthonous and allochthonous clayey nannofossil oozes, but volcanic silts appear with increasing frequency below $130 \mathrm{mbsf}$. Most of the turbidites are thinto medium-bedded, and individual turbidite beds do not reach the thicknesses recorded toward the base of the sediment column at Site 834. However, the upper $130 \mathrm{~m}$ of the section (dating from 2.9 Ma to present [Rothwell et al., this volume] and equivalent to a semitransparent sequence from 0 to $0.17 \mathrm{~s}$ TWT) consists mainly of redeposited sediments. Several episodes of instability can be inferred from the presence of single or multiple slide complexes that consist of muddy debris-flow deposits and rafts of older sediment commonly overlain by thick turbidite muds (Rothwell et al., this volume).

The extreme instability of the area around Site 835 is reflected in the dip data from both core and downhole logs. In contrast to Site 834, dips in Holes $835 \mathrm{~A}$ and $835 \mathrm{~B}$ are scattered and very high (Fig. 4C), with observations in the cores of planar surfaces inclined at up to $65^{\circ}$. It is evident, however, that many of the dipping surfaces are not tectonically tilted bedding planes that were originally horizontal: many of the very steep dips correspond to the mud-clast conglomerate horizons, and some of the surfaces are clearly the edges of mud clasts (e.g., see fig. 11 in Parson, Hawkins, Allan, et al., 1992, p. 194). Other steep dips occur at the bases of the two largest slide complexes-at $69 \mathrm{mbsf}\left(38^{\circ} \mathrm{dip}\right)$ and at $128 \mathrm{mbsf}\left(52^{\circ} \mathrm{dip}\right)$ - and were almost certainly caused by erosive scouring. Dipmeter processing of the FMS data (obtained between 75 and $171 \mathrm{mbsf}$ ) does not pick up these very steep dips because the correlation parameters used were optimized for less steeply dipping planes. Intervals of more consistent dip and dip direction were recognized, however, between 78 and $97 \mathrm{mbsf}$ and between 130 and 155 mbsf; these correspond to thinly bedded turbidites and hemipelagites. In the upper interval the dipmeter dip directions fall in the southwest quadrant, and in the lower interval in the northeast quadrant (Fig. 4C). In the lowermost few meters of the sedimentary succession, bedding dips increase to as much as $25^{\circ}$ toward the north-northwest.

It is not possible to determine on the available evidence whether these increased dips at the base of the sedimentary sequence, or indeed any of the bedding dips shown in Figure 4C, are of tectonic rather than depositional origin. If the dips are essentially depositional, as favored by Parson, Hawkins, Allan, et al. (1992), the data between 130 and 155 mbsf are compatible with the seismic evidence (discussed above) for a wedge of debris being built westward from the eastern flank, and then perhaps being channelled northward into the deeper parts of the basin. Alternatively, if the dips are tectonic, hinge faulting must have occurred to cause the northward tilting of the basin floor. There is little evidence on the seismic records described here for such northward tilting or thickening of the sedimentary infill, and, in light of the sedimentary evidence for widespread instability and redeposition, the depositional origin of the dips is preferred.

Although the dip data do not, therefore, allow episodes of activity on, or the kinematics of faults in, the sub-basin to be constrained reliably, periods of instability can be inferred from the redepositional episodes recognized in the sediment column. Because these episodes involve remobilization and introduction principally of pelagic sediments rather than volcanic detritus, we can be confident that the impetus is tectonic and not a nearby volcanic eruption. Using the stratigraphy established by Parson, Hawkins, Allan, et al. (1992), the main periods of instability at Site 835 during the last 3 m.y. are inferred as occurring between 0 and $0.4,0.9$ and 1.0, 1.4 and 1.7, and 2.1 and $2.9 \mathrm{Ma}$, on the basis of the emplacement of debris flows, rafted blocks and turbidites during these times (Fig. 3, and see Rothwell et al., this volume). The significance of these periods of instability is considered in the discussion section of this paper. 


\section{Sub-basin 836}

Site 836 was drilled on oceanic crust generated at the ELSC that is placed at $\sim 0.8 \mathrm{Ma}$, according to our interpretations of magnetic anomalies. The site is flanked by ridges in places as shallow as 1500 $\mathrm{m}$ water depth and lies in a shallow basin oriented approximately $010^{\circ}$ (Fig. 5A). The sediment at Hole 836A is only $20.2 \mathrm{~m}$ thick and consists of a sequence of clayey nannofossil oozes with interbedded turbiditic volcanic sands and silts, rare pyroclastic ashes, and thick-bedded mafic hyaloclastites overlying a MORB-like igneous basement. Sedimentation has, however, been largely hemipelagic from $0.4 \mathrm{Ma}$ to the present (i.e., from 0 to $6 \mathrm{mbsf}$ ). The last emplacement of thin- to medium-bedded turbiditic volcanic sands and silts is at about $0.4 \mathrm{Ma}$ but allochthonous beds are most frequent below $12 \mathrm{mbsf}$ (dated to approximately $0.78 \mathrm{Ma}$ ).

No logging data are available for Site 836 , but core observations indicate that the sediments dip gently $\left(1^{\circ}-4^{\circ}\right)$ throughout. Parson, Hawkins, Allan, et al. (1992) report an easterly dip direction, perpendicular to the regional structural grain, for three core measurements reoriented using either multishot or shipboard paleomagnetic declination data. The sediment dips may, in part, be a primary depositional feature, based on our interpretation of high-resolution $3.5-\mathrm{kHz}$ seismic profiles recorded by the JOIDES Resolution during Leg 135. These indicate sediment up to $70 \mathrm{~m}$ thick at the flanks of the basin, contrasting with parts of the basin floor where no sub-bottoms can be resolved, and which we interpret as scoured basement surfaces.

\section{Sub-basin 837}

Sub-basin 837 has a maximum water depth of $2760 \mathrm{~m}$ and trends north-northeast between rapidly shoaling ridges in the west $(2350-\mathrm{m}$ water depth) and a more subdued topography in the east (Fig. 5B). Seismic-reflection data suggest that these ridges may be fault controlled, but little or no disruption of the sedimentary sequence is seen within the basin fill. Locally, the seafloor shoals at the flanks of the basin, indicating some sediment redeposition, possibly as basin contourites. Core measurements show bedding dips to be as high as $17^{\circ}$ near the base of the sedimentary section (fig. 13 in Parson, Hawkins, Allan, et al., 1992, p. 306), but the number of measurements obtained are too few in number to be used as "evidence" for growth faulting. Because no downhole logging was undertaken at Site 837, no dipmeter data are available. The only constraint on the sedimentary bedding orientation comes from shipboard multishot data of unknown reliability, which suggest a broad spread of dip directions scattered over the northeastern and southeastern quadrants (Parson, Hawkins, Allan, et al., 1992).

The sedimentary sequence cored at Site 837 consists of a $69-\mathrm{m}$ thick, lower sequence (13.5-82.1 mbsf) of thick to very thick beds of normally graded, proximal vitric sands and silts deposited by sediment gravity flows. Some of these beds must have been deposited in rapid succession, as very little hemipelagic sediment has been deposited between them, although this may conceivably reflect basal scour during emplacement. This volcaniclastic-dominated lower sequence is overlain by $13.5 \mathrm{~m}$ of clayey nannofossil ooze that contains rare beds of graded foraminiferal oozes and thin vitric silts. Of this upper sequence, $11.5 \mathrm{~m}$ represents wholly hemipelagic accumulation, and consideration of average hemipelagic sedimentation rates suggests that the boundary between the predominantly volcaniclastic lower sequence and the predominantly hemipelagic upper sequence occurred at about 760$770 \mathrm{ka}$, a date supported by shipboard paleomagnetic data (Parson, Hawkins, Allan, et al., 1992). Sporadic turbidite influx has been taking place throughout the last $0.5 \mathrm{Ma}$; before this, hemipelagic accumulation predominated between 0.5 and $1.3 \mathrm{Ma}$, except for the interval $0.8-0.9 \mathrm{Ma}$, which was a period marked by the emplacement of several turbidites within a fairly short time span (Fig. 3). We have not found it possible to differentiate between these lithostratigraphic sequences on the seismic reflection profiles available.

\section{Sub-basin 838}

The sub-basin within which Site 838 was drilled is an irregularly shaped, sediment-filled trough, trending roughly northeast-southwest and deepening to greater than $2400-\mathrm{m}$ water depth (Fig. 5B). The basin trend is somewhat oblique to the average strike of the regional fabric of $010^{\circ}$. As with many of the backarc sites, the flanking ridges shoal by up to $1 \mathrm{~km}$ in water depth; GLORIA sidescan and conventional bathymetric profiling suggests that local pinnacled highs occur on some of the ridge crests. Clear examples of individual seamounts are present in the ELSC-generated crust to the east and can be recognized, we believe, in parts of the western Lau Basin (Fig. 2, and see Fig. 6B); however, the highs in the immediate vicinity of Sites 838 and 839 appear to be broader platformal structures. One interpretation of these features is that they represent slivers of the fragmented paleo-arc.

Site 838 was located close to the northwestern flank of the subbasin, in approximately $2320 \mathrm{~m}$ of water. Seismic reflection profiles recorded by the JOIDES Resolution, illustrated in Parson (this volume), show the upper part of the seismic section to comprise a sequence of parallel, weakly undulating reflectors, cut by faults, of which some outcrop at the surface. The basin is bounded to the southeast by a northeast striking fault that dips toward $335^{\circ}$. "Acoustic basement" is difficult to trace on the JOIDES Resolution profiles; preliminary interpretations of the sediment thickness at Site 838 made before drilling during Leg 135 were incorrect: igneous basement was not reached despite 259.20 m of penetration (Parson, Hawkins, Allan, et al., 1992).

The seismic data suggest that the sedimentary sequence thickens toward the southeast from the drill site into the main part of the subbasin, within which at least $0.45 \mathrm{~s}$ TWT of sediment is recognized. The profiles also appear to suggest that the seismic reflectors themselves dip south- or southeastward. This is confirmed by FMS dipmeter downhole logging data from Hole 838B (Fig. 5C), which show the sediments to be relatively steeply inclined $\left(10^{\circ}-30^{\circ}\right)$, with a uniform dip direction toward the east-southeast. We think that the magnitude of the dip and uniformity of dip direction is good evidence that tectonic tilting was responsible for at least some of the bedding inclination. The bedding dips toward, and is approximately perpendicular to, the northeast-striking, northwest-dipping structure that bounds the southeastern edge of the sub-basin. The simplest explanation of the data is that tilting of the sediment sequence was effected by rotational ("listric") normal faulting about this fault.

The dipmeter dips show no systematic variation within the logged interval (57-229 mbsf), and therefore on their own do not help constrain the timing of tilting. Bedding dip measurements from Hole 838A cores, however, do show a pronounced increase in dip between 25 (or 40?) and 50 mbsf (Fig. 5C), and may be taken to suggest that tilting occurred in the time period corresponding to this stratigraphic interval.

Sedimentological studies of the core show that this interval corresponds to the uppermost part of the lithostratigraphic Unit II (Parson, Hawkins, Allan, et al., 1992), and just predates a profound change in sedimentation style, from influx of thick, volcaniclastic-dominated mass-flow deposits, to deposition of hemipelagites at approximately 1.6-1.7 Ma (Fig. 3). The uppermost $23 \mathrm{~m}$ of the sediment column (Unit I) consists mainly of hemipelagic sediments, with the exception of a single sandy turbidite and one mud-clast conglomerate horizon (Fig. 3; also see Rothwell et al., this volume). Coarse volcaniclastic sediments dominate the remaining $236 \mathrm{~m}$ penetrated at Site 838 . This lower sequence (Units II and III on Fig. 5C) is composed principally of proximal gravity-flow deposits, including very thick vitric gravels, with only minor interbeds of hemipelagic clayey nannofossil oozes. Although core recovery was very poor below $100 \mathrm{mbsf}$ (2.9\%; Parson, Hawkins, Allan, et al., 1992), the FMS borehole images clearly distinguish between oozes and the coarse volcaniclastics, and show that gravels comprise an approximately $85 \%$ of the succession between 100 and 230 mbsf. These coarse volcaniclastic sediments are interpreted as proximal mass-wasted deposits, which probably 
A.
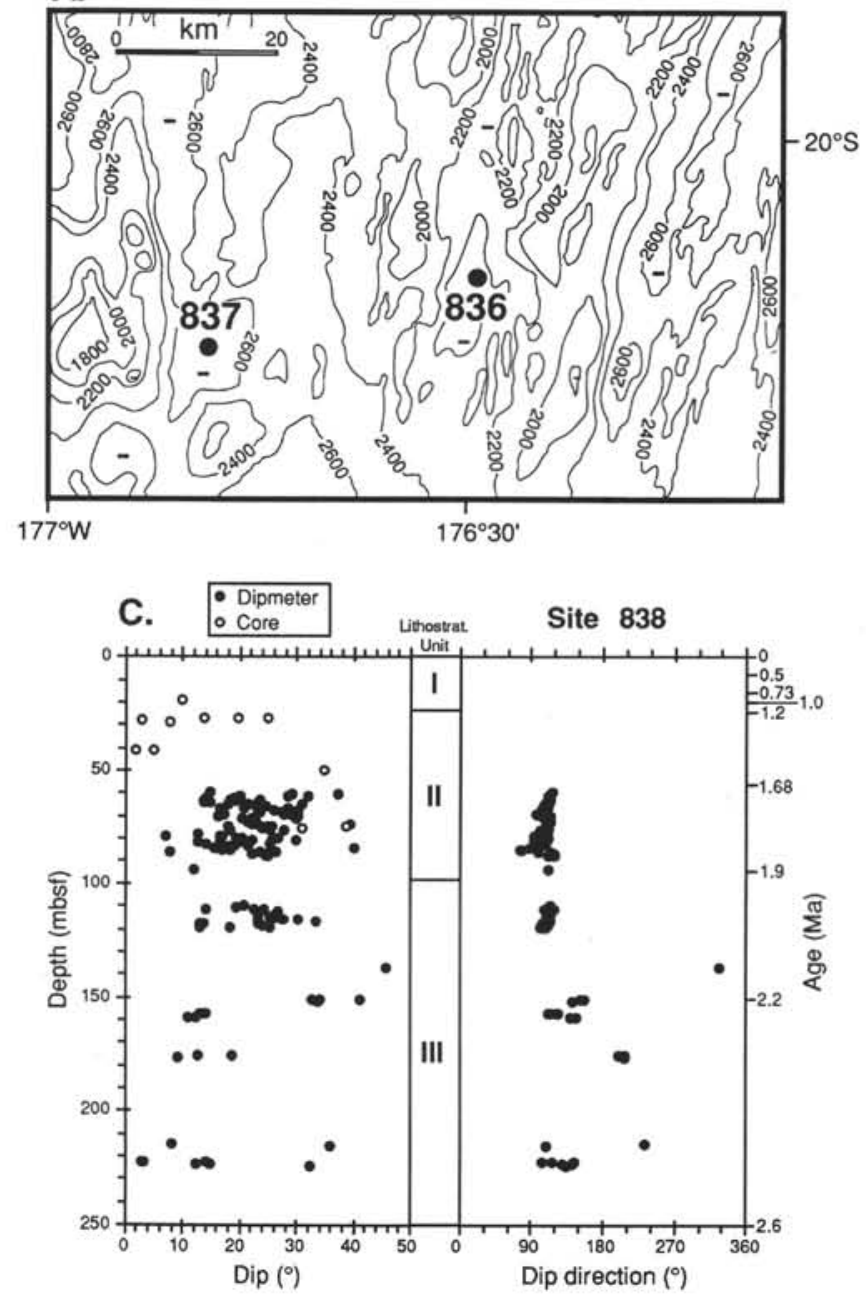

B.
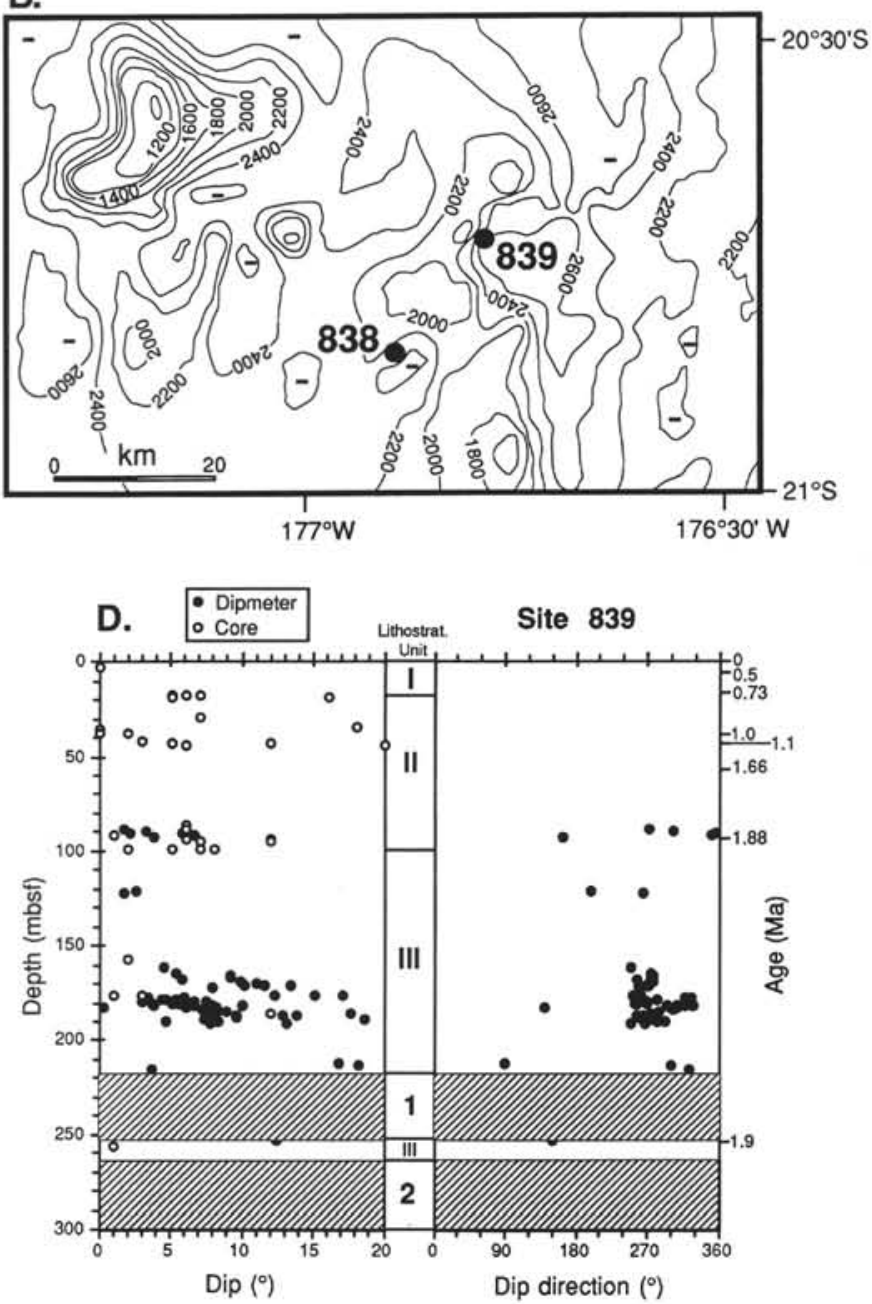

Figure 5. A. Detailed bathymetry in the vicinity of Sites 836 and 837. B. Detailed bathymetry in the vicinity of Sites 838 and 839 . C. Dipmeter and core dip measurement summary for Site 838. D. Dipmeter and core dip measurement summary for Site 839 .

formed coarse-grained volcaniclastic aprons around the basement ridges that bound the sub-basin.

\section{Sub-basin 839}

Site 839 lies approximately $20 \mathrm{~km}$ northeast of Site 838 , in an irregularly shaped, north-northeast to northeast-elongated sub-basin approximately $15 \mathrm{~km}$ long $\times 5-10 \mathrm{~km}$ wide (Figs. 2 and 5B). Several different steep, linear scarps recognized on recent bathymetric compilations and on GLORIA sidescan sonar mosaics (Parson et al., 1992) delineate faults that bound the basin at least on its western and northwestern sides. The orientations of major fault structures in the vicinity of both Sites 838 and 839 are significantly less consistent than those north-northwest features defining the sub-basins examined to the north, and several distinct trends can be identified. The GLORIA records show that most faults strike either north or northeast, but a significant number of east-trending scarps exist, and many have variable trends. The relative chronology of fault families is unfortunately not clear with the available data.

Seismic reflection profiler data recorded by the JOIDES Resolution across the Site 839 sub-basin is illustrated in Parson, Hawkins, Allan, et al. (1992) and Parson (this volume), and an interpretation is given in Parson, Hawkins, Allan, et al. (1992). Above an acoustic basement at a depth of approximately $0.25 \mathrm{~s}$ TWT, planar, northwest- dipping reflectors are overlain with sharp angular unconformity by a sequence of subhorizontal, parallel-bedded, planar reflectors. The reflectors are bounded to the northwest by a fault scarp that correlates with the northeast-trending, basin-bounding fault recognized on the GLORIA sonographs. Integration of the seismic data with shipboard velocity measurements on the core (Parson, Hawkins, Allan, et al., 1992) suggests that the unconformity should correspond to a depth of approximately $100 \mathrm{mbsf}$.

The FMS dipmeter data from Hole 839B show a relatively uniform west to west-northwesterly bedding dip within the logged interval of the sediment column (81-214 mbsf; Fig. 5D). Because of poor hole conditions and/or unsuitable lithology, few dip correlations were obtained between 100 and $150 \mathrm{mbsf}$. Above $100 \mathrm{mbsf}$, dipmeter dips are all less than or equal to $7^{\circ}$, whereas below $150 \mathrm{mbsf}$ dips range much higher (up to $19^{\circ}$ ). Two dipmeter measurements at $\sim 120 \mathrm{mbsf}$ are both shallowly dipping. These data (Fig. 5D) suggest that the unconformity should lie somewhere in the depth range $100-150 \mathrm{mbsf}$.

In the core this depth interval corresponds to the base of lithologic Unit II ( $99.5 \mathrm{mbsf}$ ) and upper parts of Unit III, and a date of approximately $1.9 \mathrm{Ma}$. Units II and III are dominated by coarse volcaniclastic deposits, overlain, as at all of the other sites, by a hemipelagic, clayey nannofossil ooze sequence (Unit I). The changeover from volcaniclastic-dominated to hemipelagic deposition (corresponding to the Unit I/II boundary) took place here at $0.8 \mathrm{Ma}$ (Fig. 3 ). 
The sedimentary succession at Site 839 is $214 \mathrm{~m}$ thick (with a further thin sediment interbed between lava flows at $\sim 260 \mathrm{mbsf}$ ); as at Site 838, the lower volcaniclastic interval is extremely thick (180-200 $\mathrm{m}$ ), with the upper clay nannofossil ooze unit very much thinner. Sedimentation rates were extremely high: Parson, Hawkins, Allan, et al. (1992) estimate an average rate of $\sim 880 \mathrm{~mm} / \mathrm{k} . \mathrm{y}$. below approximately 60 mbsf. Although core recovery below 99.5 mbsf was extremely poor $(2.6 \%)$, some volcanic gravels and vitric sands and silts were recovered, suggesting that the lower half of the sedimentary succession is dominated by coarse volcaniclastic sediments, as at Site 838. Unfortunately, the FMS images from Site 839 are not of sufficient quality for a synthetic lithological log to be reconstructed from them.

Taken together, the seismic, structural, and sedimentological data from Site 839 suggest that rotational normal faulting took place about the northeast-striking, southeast-dipping fault that bounds the subbasin to the northwest (possibly with a contribution from the northstriking, east-dipping fault to the west of the site?), tilting the rapidly deposited volcaniclastic sediments west-northwestward. This activity took place approximately $1.9 \mathrm{Ma}$ ago. Deposition of volcaniclastic sediments continued after the tilting "event," ceasing only at about $0.8 \mathrm{Ma}$.

\section{INTERPRETATION OF S.P. LEE SEISMIC PROFILE 31}

USGS single-channel seismic profile 31 crosses the Lau backarc basin at an average azimuth of $100^{\circ}$ (Fig. 1), and passes within $1 \mathrm{nmi}$ of Site 839 and $10 \mathrm{nmi}$ of Site 838. Rather than reproduce the whole profile here, we have selected sections of this profile to illustrate key processes and styles of basin formation. These form Figures 6A-6D.

The westernmost sedimentary deposits in the Lau Basin are characterized by a gently undulating surface, overlying a layer parallel seismic sequence that extends to a maximum of $0.85 \mathrm{~s}$ TWT below seafloor (Fig. 6A). The majority of the section is dominated by conformable parallel seismic reflectors, with little evidence for angular or stratigraphic unconformities. Undulations in the topography do not appear to result from compressional deformation (e.g., fold buckling), as the upper sequence appears to be dominated by a pelagic drape over a highly irregular acoustic basement topography. Basement is not well resolved beneath the thick sediment cover, and only the crests of buried ridges are clear. Therefore, we can only speculate on the effect that differential compaction may have had on the internal basin structure. Locally, large-scale recent fault motions are documented by the seismic reflection data. Figure $6 \mathrm{~A}$ illustrates the effects of reactivation of basement-controlling structures on the pelagic sediments that mantle them. A minimum estimate of the local extension can be made from the cumulative amount of horizontal offset of an assumed flat-lying basement surface. We calculate this figure to be in the order of $15 \%$, but in reality it could be significantly more than this. The competent drape unit has deformed without apparent faulting to form a gentle west-facing half-graben. This sub-basin has been filled with a unit characterized by easterly fanning reflectors, suggesting continuously active growth faulting on the controlling structure. We have no means of testing how variations in sediment supply may have influenced the style of basin fill.

At $20^{\circ} 36^{\prime} \mathrm{S}, 177^{\circ} 05^{\prime} \mathrm{W}$, the seismic profile crosses a shallow area that reaches a water depth of $911 \mathrm{~m}$ (Fig. 6B). Apart from the Zephyr Shoal in the north, this depth is the shallowest recorded in the central Lau Basin. It has a steep-sided profile to the west, dropping more than $1800 \mathrm{~m}$ in $7 \mathrm{~km}$, and cut by a number of steep faults, some of which have slope angles up to $39^{\circ}$. These faults outline a series of narrow blocks with weakly laminated upper surfaces, suggesting some sediment cover. On its eastern side, the high has a more gently sloping flank, a chaotic mounded slope and slump folds on the upper slopes, and a series of terraced sedimentary blocks, separated by moderately dipping normal faults. A recent compilation of Sea Beam and conventional bathymetric data (Parson et al., 1992) shows that the shoal area is a discrete, irregularly shaped, knoll-like feature, apparently steeper in the west than in the east, rather than the peak of a ridge. We interpret the minimal sediment cover and the extreme relief as suggesting that the feature represents the remnants of a fault-dissected and partially dismantled volcanic construct. It is argued elsewhere (Parson, Hawkins, Allan, et al., 1992, pp. 5-47) that these features are common in the western basin, built as a consequence of the easterly migration of the locus of active arc volcanism during crustal attenuation before the onset of true backarc spreading. We recognize several of these inferred volcanic arc constructs (Fig. 2), together with a number of more elongate features that we tentatively interpret as examples of discrete elevated sections of the remnant fragments of the Lau-Tonga proto-arc.

The west face of the arc shoal depicted in Figure 6B drops down to the floor of an approximately north-south rift valley deepening to more than 2775 mbsl, illustrated in Figure 6C. This area of the western Lau Basin was insonified by GLORIA long-range sidescan sonar survey in 1988 (Parson et al., 1989). These data reveal brightly backscattering seafloor occurring in a broad band, flanked by linear targets that are thought to represent fault scarps. Our tentative interpretation of these seafloor textures is that a limited amount of extrusive off-axis volcanism has taken place recently within the rift, which lies some $230 \mathrm{~km}$ from the present location of the ELSC. On the seismic section, the absence of sub-bottom reflectors and the hummocky irregular surface tend to support this interpretation. Although there are no sample data to confirm this suggestion directly, anomalously high levels of hydrothermally derived recent sediments are reported in the area by Hodkinson and Cronan (1991). An alternative explanation for the brightly backscattering seafloor is that it represents a broad area of recent mass-wasting or debris-flow deposits. This would concur with the interpretations made by von Stackelberg et al. (1990) of $3.5-\mathrm{kHz}$ profiles across highly reflective zones in the vicinity of Sites 834 and 835 . Thermal anomaly data is no help in resolving this matter, as Sites 838 and 839 , the closest drill sites to this area ( $40 \mathrm{~km}$ away) have the highest and the lowest heat-flow values, respectively, of any of the records for Leg 135 . We surmise that, at the very least, the data provide evidence for recent tectonic activity and, at most, a combination of faulting and localized off-axis volcanism.

The final section of the USGS line 31 we present to summarize the commonest sedimentary basin styles of the western Lau Basin (Fig. 6D). The horst-and-graben (and half-graben) structures that control the morphology of the basins are clearly illustrated by both east- and west-facing faults. At margins to the basins, single controlling faults and composite nested fault structures are observed with equal frequency (see also Fig. 2). Preliminary calculations suggest a minimum of approximately $16 \%$ extension across this section of the basin, estimated by using fault offsets of basement. At the eastern end of the section shown in Figure 6D the basement apparently lacks significant sediment cover, and corresponds with the westward limit of crust formed at the ELSC. The deep basin that forms the central part of the section in Figure 6D marks the intersection with the outer propagating rift "pseudofault."

\section{DISCUSSION}

Our observations and interpretations of the available seismic reflection data in the western Lau Basin confirm that the irregular horst-and-graben topography has been generated by a combination of extensional faulting and arc construction. In a general sense, suggestions of west-to-east migration of arc volcanism during the early opening of the basin are substantiated by the drilling results, but it is less clear that the pattern of regional extensional strain has been as systematic. Indeed, the persistence of off-axis tectonism (and possibly volcanism) suggests that the processes are more heterogeneous.

We can summarize the structural style of the sub-basins as dominated by graben and half-graben forms that are bounded by upstanding fragments of the Lau Ridge or more recent arc volcanic centers. Where 

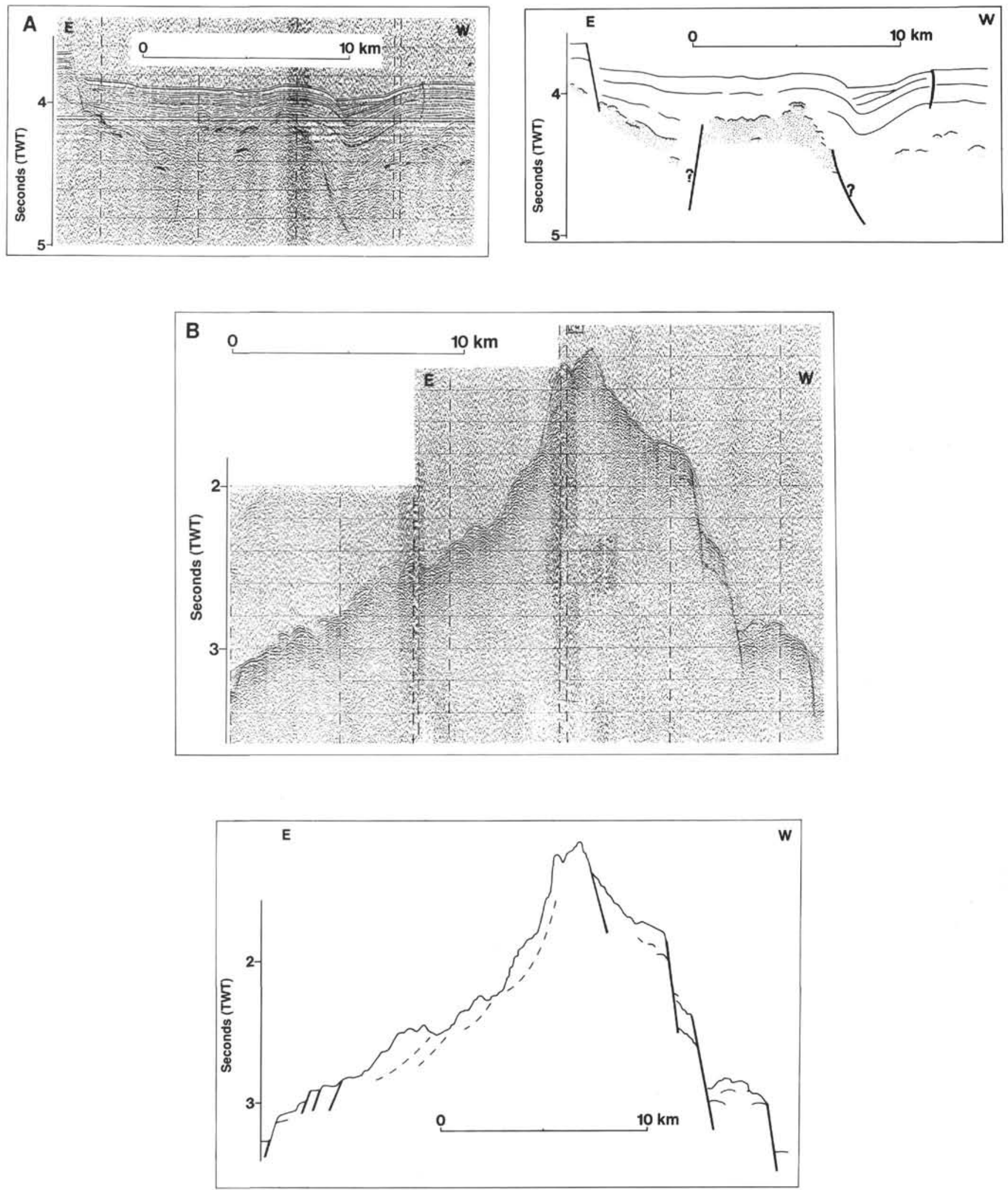

Figure 6. Selected sections of USGS S.P. Lee line 31, with line interpretations. A. Thick sedimentary sections mantling irregular basement topography adjacent to the Lau Ridge. Fault characteristics and half-graben feature discussed in text. B. Shallow, subequant rise, provisionally interpreted as a partially faulted arc construct. Note slump structures on eastern flank. C. Floor of rift structure central to the western Lau Basin, characterized by minimal sediment cover, corresponding to area of high backscatter recorded by GLORIA data (Parson et al., 1989). D. Faulted sedimentary section adjacent to Site 839, illustrating half-graben and graben structures typical of basin style in the western Lau Basin. 
C
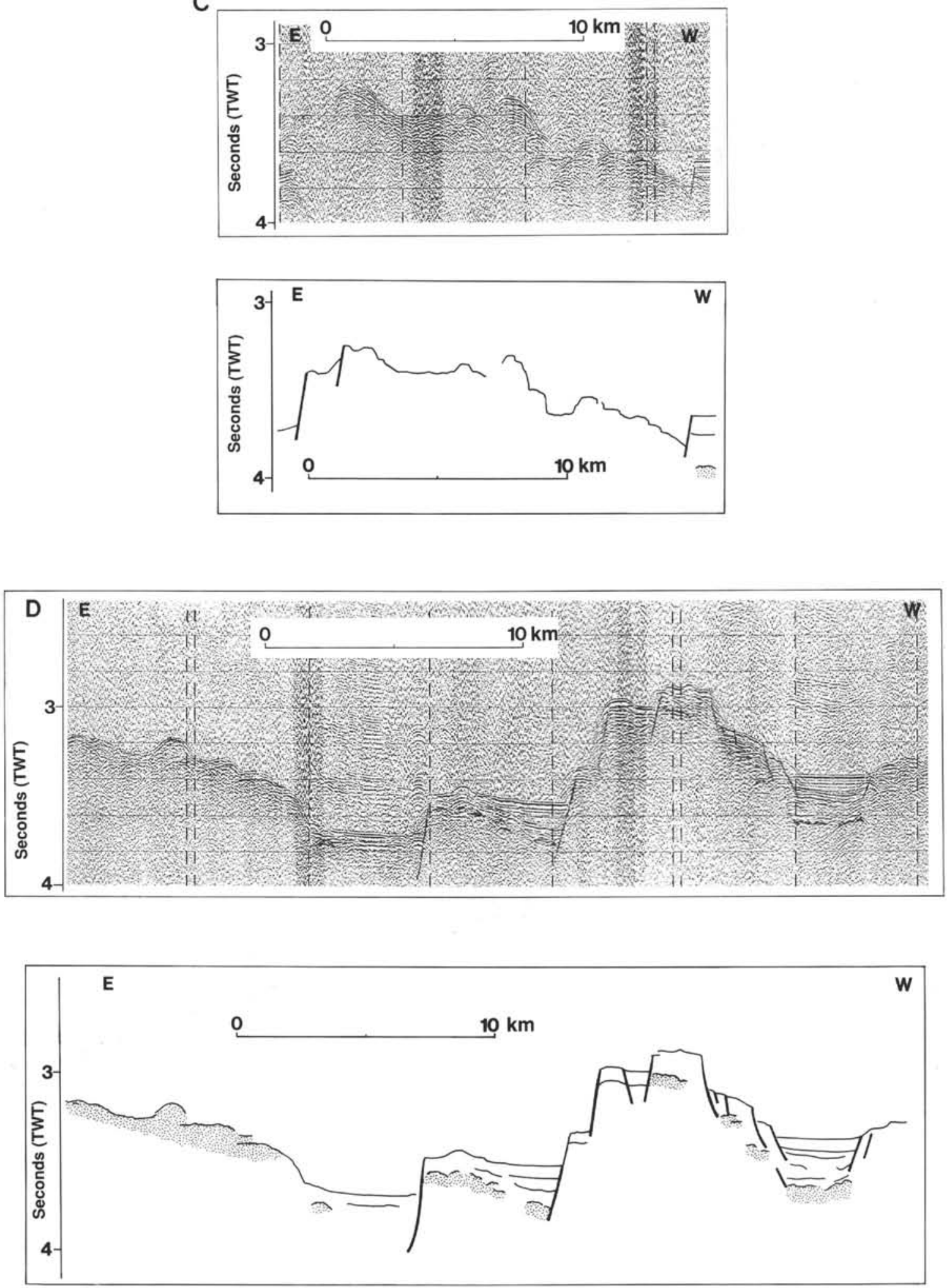

Figure 6 (continued). 
the seismic records permit, we calculate minimum extensional strains of the order of $15 \%$; this value does not take into account, however, any extension caused by volcanic intrusive activity. The regional morphology has been further modified by slumping and mass-wasting processes throughout the lifetime of the basin, as evinced by the rafted blocks drilled at Site 835 and surface effects to the west of Sites 838 and 839 .

The possible controls on sedimentation in the sub-basins of the western Lau Basin fall into two categories: (1.) volcanic factors, and (2.) tectonic factors. In the following sections we discuss the likely regional and/or local effects of these two factors in the context of our observations presented above.

\section{Volcanic Controls on Sedimentation}

We consider here the possible regional and local effects that extrusive volcanism has had in the Lau Basin. Principal local contributions to the sub-basin fills are likely to have included:

1. Western basin volcanism. During the early evolution of the Lau Basin, an easterly migration of arc volcanism may have occurred before the initiation of the backarc spreading axis. Many of the drill sites record very proximal recent volcanic events or mass-wasted products derived from young arc constructs. Their contribution to the sediment fill of the sub-basins is likely to be significant.

2. Present off-axis volcanism. Although the occurrence of offaxis volcanism has yet to be determined beyond doubt, there are strong indications that it persists in the western basin well after the establishment of a "true" backarc spreading axis.

There are five principal regional sources that we consider might have provided volcanic input to the Lau Basin:

1. Lau Ridge volcanism. Active volcanism continued on the Lau Ridge until at least $3.5 \mathrm{Ma}$ (Gill, 1976), and the eroded products from the remnant arc are likely to have made a significant contribution to the basins adjacent to the east flank.

2. Tofua arc volcanism. Clift and Dixon (this volume) document an increase in volcaniclastic input at approximately $3 \mathrm{Ma}$ at Site 840 that they ascribe to the initiation of the Tofua volcanic arc. Parson and Hawkins (this volume), however, suggest that the onset of arc volcanism along its present line is likely to have been diachronous from north to south, spatially and temporally linked with the southward propagation of the ELSC and the establishment of a "typical" trench-arcbackarc setting. Few other data exist to test this hypothesis or allow the age of the initiation of the Tofua Arc to be established with any greater certainty.

3. Propagator tip volcanism. The passage of both the earlier ELSC and the subsequent CLSC through the Lau Basin may have been associated with an increase in volcanic activity. Detailed examination of mid-ocean-ridge propagator ridge tips indicates large-scale tectonic but minimal magmatic activity (Hey et al., 1986); therefore, the CLSC as an analog may be discounted as a significant contributor. The ELSC, however, had to advance through an attenuated heterogenous basement complex, and the uplift/subsidence and the associated volcanic effects in such a setting are largely unknown.

4. Maturing axis volcanism. The ELSC and the CLSC may each be responsible for volcanic input to the Lau Basin after establishing a "normal" backarc spreading axis. The amount of extrusive volcanism associated with these axes is difficult to quantify and thus remains speculative.

5. Distal volcanic sources. The contribution of volcanic detritus from explosive/extrusive centers some distance from the central Lau Basin cannot be discounted. Although the volcaniclastic material drilled during Leg 135 was overwhelmingly of epiclastic (reworked) origin, an input from surface-drifted supply (in the form of pumice rafts) over hundreds or even thousands of kilometers is not precluded.
Such sources could include shoal areas such as Zephyr Shoal, Donna Ridge, and Rochambeau Bank, each lying to the north of the Peggy Ridge, and each of unknown and possibly primary volcanic constructional origin. Zephyr Shoal is approximately $260 \mathrm{~km}$ from the northernmost Leg 135 site (Site 835) and more than $500 \mathrm{~km}$ from the most distant (Site 838). Primary pyroclastic air-fall tuffs in Leg 135 cores are rare, but those that were identified may be derived from the Taupo ignimbrite eruptions (A. Ewart, pers. comm., 1991) as a result of active volcanism and extensional tectonism in the Taupo Volcanic Zone on North Island, New Zealand, over the last 1 m.y.

\section{Tectonic Controls on Sedimentation}

It is clear from our observations above that local tectonic effects in individual sub-basins play a significant role in controlling sediment accumulation, and that these effects are diachronous. It is less obvious, however, how we can reliably quantify or chronicle the controls on tectonism. The approach we have taken is to use the local lithostratigraphies and tilting histories from the Leg 135 backarc drill sites to estimate the times of peak extensional deformation at each site (Fig. 3). The broader scale regional tectonic "events" that we can identify as having possible influence on local-scale tectonism are as follows:

1. As the basin opens we might expect, intuitively, that the locus of extensional strain should be transferred across the basin during arc rifting, in much the same way as the locus of arc volcanism migrated eastward with time. The occurrence of local tectonic activity in the western basin as reported above, however, indicates that the pattern of strain transfer is not totally systematic.

2. The transition between horst-and-graben-style rifting to active seafloor spreading was finally completed with the initiation of the ELSC, but our drilling results indicate that the basements of some of the rift basins in the western Lau Basin have a distinct MORB-like affinity. This suggests that short-lived spreading centers may have developed and failed, perhaps repeatedly across the basin, before the successful establishment of true backarc spreading.

3. The tectonic effects of the propagation of the ELSC and CLSC rift tips, and the development of their associated "pseudofaults," are likely to have been significant on a local scale. Studies of open-ocean propagators indicate that increased extensional tectonism occurs in the vicinity of the rift tip, and this is confirmed in the Lau Basin by the imaging on GLORIA records of dense arrays of normal strike-slip structures at, or immediately in advance of, the tip. Fortunately, we are able to assess the possible effects of rift propagation using the model of Parson and Hawkins (this volume), which predicts with some precision the position of the tips at all times since their initiation. In Figure 3, we have indicated the times at which the two propagating rifts have passed each of the drill sites. It is clear from this figure that the periods of increased sedimentary activity, as recorded by influx of turbiditic sediments or slumping, correlate moderately well with the closest approach of the propagators to each sub-basin. Local tectonic activity, in the form of normal faulting and tilting on basinbounding structures, correlate extremely well with the passage of the ELSC propagator. The effects of the CLSC, however, are less readily recognizable, and appear to be much less significant. This is probably because the CLSC rift tip did not approach as close to the sub-basins under investigation as did the ELSC and, furthermore, because the CLSC did not have to rift the thicker, older, more heterogeneous arc crust.

4. It is possible that the southward migration of the zone of collision of the Louisville Ridge seamount chain with the Tonga Trench (Fig. 1) might have had some effect on tectonism and sedimentation within the Lau Basin, as proposed by Dupont and Herzer (1985) for the Tonga Ridge. Using the plate convergence vectors given by Lonsdale (1986) we can constrain the timing of collision at the latitude of each site with some precision; however, there is no obvious correlation with the observed episodes of tectonism or 
changes in sedimentary input. Indeed, Clift (this volume) and MacLeod (this volume) show that, even in the Tonga forearc itself, the effects of the Louisville Ridge subduction are limited.

\section{SUMMARY AND CONCLUSIONS}

It is not possible to make a rigorous assessment all of the possible controls on sedimentation in the Lau Basin, but some general conclusions can be drawn from our synthesis of seismic, sedimentological, and structural data.

The volcaniclastic input to the sub-basins in the horst-and-graben terrain of the western Lau Basin is predominantly of local derivation. Bathymetric and seismic data confirm a general lack of interconnectivity and sediment transport between the sub-basins, and the volcaniclastic sediments are compositionally and texturally immature. Much of this volcaniclastic input is likely to be of proximal origin, derived from the high-standing relict arc fragments and/or volcanic constructs that separate the sub-basins within the western Lau Basin itself.

Graben formation and infilling is diachronous across the western Lau Basin. A twofold subdivision of the sedimentary succession is recognized in all of the western Lau Basin sites, between a volcaniclastic turbidite-dominated sequence below and a hemipelagite-dominated sequence above. The timing of maximum turbidite emplacement, however, differs from sub-basin to sub-basin. The principal phase of activity on the faults that bound the individual graben or sub-basins (as documented by the sediment tilting history) is accompanied by accelerated sedimentary influx to that particular sub-basin, presumably from the redeposition of detritus from adjacent highs. The converse, however, is not necessarily the case. The peak of activity on the basinbounding normal faults appears to straddle the time of the closest approach of the ELSC-propagating rift tip to each sub-basin (Fig. 3). This suggests that the transition from rifting to seafloor spreading is heralded by increased extensional tectonism of the rifted arc crust, and then a decrease as extension is taken up by the spreading center.

\section{ACKNOWLEDGMENTS}

Seismic reflection profile LEE 31 was made freely available to us by the United States Geological Survey, to which we are deeply indebted. In particular, Dave Scholl of the USGS contributed much time and probably exhausted even his patience in commenting on our early attempts to draft this paper. Our thanks also go to another anonymous reviewer. We thank Ian Mitchell for his efforts in drafting the figures, and the Natural Environment Research Council for financial support.

\section{REFERENCES}

Dupont, J., and Herzer, R.H., 1985. Effect of subduction of the Louisville Ridge on the structure and morphology of the Tonga Arc. In Scholl, D.W. and Vallier, T.L. (Eds.), Geology and Offshore Resources of Pacific Island
Arcs-Tonga Region. Circum-Pac. Counc. Energy Miner. Resour., Earth Sci. Ser., 2:323-332.

Herzer, R.H., and Exon, N.F., 1985. Structure and basin analysis of the southern Tonga forearc. In Scholl, D.W., and Vallier, T.L. (Eds.), Geology and Offshore Resources of Pacific Island Arcs-Tonga Region. CircumPac. Counc. Energy Miner. Resour., Earth Sci. Ser., 2:55-73.

Hey, R.N., Kleinrock, M.C., Miller, S.P., Atwater, T.M., and Searle, R.C., 1986. Sea Beam/deep-tow investigation of an active oceanic propagating rift system, Galapagos $95.5^{\circ}$ W. J. Geophys. Res., 91:3369-3393.

Hodkinson, R.A., and Cronan, D.S., 1991. Geochemistry of Recent hydrothermal sediments in relation to tectonic environment in the Lau Basin, southwest Pacific. Mar. Geol., 98:353-366.

Lonsdale, P., 1986. A multibeam reconnaissance of the Tonga Trench axis and its intersection with Louisville Guyot Chain. Mar. Geophys. Res., 8:295-327.

Mann, D.M., 1985. Multichannel profiles collected in 1982 in the Tonga region of the South Pacific. In Scholl, D.W., and Vallier, T.L. (Eds.), Geology and Offshore Resources of Pacific Island Arcs-Tonga Region. Circum-Pac. Counc. Energy Miner. Resour., Earth Sci. Ser., 2:49-54.

Mazzullo, J.M., Meyer, A., and Kidd, R., 1987. New sediment classification scheme for the Ocean Drilling Program. In Mazzullo, J., and Graham, A.G. (Eds.), Handbook for Shipboard Sedimentologists. ODP Tech. Note, $8: 45-67$.

Parson, L., Hawkins, J., Allan, J., et al., 1992. Proc. ODP, Init. Repts., 135: College Station, TX (Ocean Drilling Program).

Parson, L.M., et al., 1989. Charles Darwin Cruise 33/88, 5 May-1 June 1988. Geophysical surveying and geological sampling in the Lau back-arc basin. SW Pacific Ocean. Inst. Oceanogr. Sci. Deacon Lab. Cruise Rep., 206.

Parson, L.M., Hawkins, J.W., and Hunter, P.M., 1992. Morphotectonics of the Lau Basin seafloor-implications for the opening history of backarc basins. In Parson, L., Hawkins, J., Allan, J., et al., Proc. ODP, Init. Repts., 135: College Station, TX (Ocean Drilling Program), 81-82.

Parson, L.M., Pearce, J.A., Murton, B.J., Hodkinson, R.A., Bloomer, S., Ernewein, M., Huggett, Q.J., Miller, S., Johnson, L., Rodda, P., and Helu, S., 1990. Role of ridge jumps and ridge propagation in the tectonic evolution of the Lau back-arc basin, southwest Pacific. Geology, 18:470-473.

Reich, V., Marchig, V., Sunkel, G., and Weiss, W., 1990. Hydrothermal and volcanic input in sediments of the Lau back-arc basin, S.W. Pacific. Mar: Min., 9:183-203.

Schlumberger, 1986. Dipmeter Interpretation Fundamentals: New York (Schlumberger), SMP-7002.

Stevenson, A.J., 1985. Single-channel seismic and geopotential data collection and processing. In Scholl, D.W., and Vallier, T.L. (Eds.), Geology and Offshore Resources of Pacific Island Arcs-Tonga Region. Circum-Pac. Counc. Energy Miner. Resour., Earth Sci. Ser., 2:27-29.

von Stackelberg, U., et al., 1990. Hydrothermal mineralisation of the Lau Basin: results of the SONNE Cruise SO48. Mar. Min., 9:2.

\footnotetext{
Abbreviations for names of organizations and publication titles in ODP reference lists follow the style given in Chemical Abstracts Service Source Index (published by American Chemical Society).
}

Date of initial receipt: 14 October 1992

Date of acceptance: 28 July 1993

Ms 135SR-111 